\title{
Prevention of In Vitro Neutrophil Adhesion to Endothelial Cells through Shedding of L-Selectin by C-Reactive Protein and Peptides Derived from C-Reactive Protein
}

\author{
Christine Zouki, Micheline Beauchamp, Chantal Baron, and János G. Filep \\ Research Center, Maisonneuve-Rosemont Hospital, Department of Medicine, University of Montréal, Montréal, Québec, \\ Canada H1T $2 M 4$
}

\begin{abstract}
C-Reactive protein (CRP), the classic acute-phase reactant in humans, diminishes accumulation of neutrophils at inflammatory sites. To evaluate the underlying mechanisms, we have studied whether CRP and peptides derived from CRP could affect the first step of neutrophil extravasation, the L-selectin-mediated interaction of neutrophils with endothelial cells. CRP markedly attenuated attachment of human neutrophils to cultured LPS-activated human coronary artery and pulmonary microvascular endothelial cells with apparent $\mathrm{IC}_{50}$ values of 20 and $22 \mu \mathrm{g} / \mathrm{ml}$, respectively. At similar concentrations, CRP rapidly downregulated the expression of L-selectin on the neutrophil surface, whereas it failed to affect expression of CD11b and CD45 or to induce granule enzyme release. The loss of L-selectin was due to cleavage and shedding of the molecule from the cell surface, as quantitated by the soluble form of L-selectin in cell-free supernatants. The effects of CRP could be prevented by an antiCRP antiserum and by KD-IX-73-4, which inhibits shedding of L-selectin. Inhibition of adhesion with CRP was additive with function-blocking anti-E-selectin and anti-CD18 antibodies, but was not additive with anti-L-selectin antibody. Neutrophil attachment and L-selectin expression were also diminished by CRP peptides 174-185 and 201-206, but not peptide 77-82, albeit these peptides showed a weaker inhibitory effect than the parent protein. These studies indicate a specific activation-independent action of CRP and CRP peptides 174-185 and 201-206 on expression of L-selectin, and suggest that by attenuating neutrophil adhesion to the endothelium and consequently neutrophil traffic into tissues, native CRP and peptides 174-185 and 201-206 may be major mechanisms to attenuate or limit the inflammatory response. (J. Clin. Invest. 1997. 100:522-529.) Key words: $\mathrm{C}$-reactive protein $\bullet$ adhesion molecules $\bullet$ L-selectin $\bullet$ neutrophils • inflammation
\end{abstract}

\section{Introduction}

C-Reactive protein $(\mathrm{CRP})^{1}$ is a prototypical acute-phase reactant. In healthy subjects, serum concentration of CRP is $<1$

Address correspondence to János G. Filep, M.D., Research Center, Maisonneuve-Rosemont Hospital, University of Montréal, 5415 boulevard de l'Assomption, Montréal, Québec, Canada H1T 2M4. Phone: 514-252-3563; FAX: 514-252-3569.

Received for publication 7 November 1996 and accepted in revised form 2 May 1997.

J. Clin. Invest.

(C) The American Society for Clinical Investigation, Inc. 0021-9738/97/08/0522/08 \$2.00

Volume 100, Number 3, August 1997, 522-529

http://www.jci.org $\mu \mathrm{g} / \mathrm{ml}$. However, serum levels can increase as much as 1,000 fold within $24 \mathrm{~h}$ after the onset of inflammation or tissue damage (1), suggesting that this protein may initiate and/or modulate multiple responses of the host. In general, the magnitude of the CRP response is related to the severity of inflammation or the extent of tissue injury (2). Since extravasation and activation of neutrophil granulocytes are essential in the inflammatory response, the effects of CRP on these cells are of particular importance. CRP binds with high affinity to human neutrophils $(3,4)$ and inhibits neutrophil activation, including chemotaxis (5), influx into alveolar space $(6,7)$, and superoxide production and degranulation in response to FMLP and platelet-activating factor (8). Stimulation of neutrophils activates a membrane-associated serine protease which leads to cleavage of biologically active peptides from CRP (9). CRP peptides 77-82 and 201-206 have been found to inhibit neutrophil chemotaxis to FMLP in vitro (10) and to diminish neutrophil influx and protein leakage into alveoli after FMLPinduced inflammation in mice (11).

Neutrophil extravasation into inflamed or injured areas involves a complex interaction of leukocytes with endothelial cells via regulated expression of surface adhesion molecules $(12,13)$. The initial attachment of neutrophils to endothelium is mediated by L-selectin (CD62L) (12-15). L-Selectin is constitutively expressed by neutrophils and is released from neutrophils by a proteolytic cleavage within minutes after activation with a concomitant upregulation of Mac-1 (CD11b/CD18) $(16,17)$. The CD18 integrins, Mac-1 and LFA-1 (CD11a/ CD18), are largely responsible for subsequent tightening of the adhesion and transendothelial migration of neutrophils via interactions with their endothelial counterreceptors, ICAM-1 and ICAM-2 $(12,13)$.

This study was undertaken to examine whether CRP and CRP peptides could affect the first step of neutrophil extravasation, the L-selectin-mediated interaction of neutrophils with endothelial cells. We found that CRP at clinically relevant concentrations and CRP peptides 174-185 and 201-206, but not peptide 77-82, strongly inhibited adhesion of neutrophils to cultured endothelial cells. This was due to the loss of L-selectin expression in neutrophils through a shedding mechanism.

\section{Methods}

Antibodies and reagents. In these studies, the monoclonal antibodies (mAbs) used included FITC-conjugated mouse anti-human L-selectin mAb DREG-56 (PharMingen, San Diego, CA), R-phycoerythrinconjugated mouse anti-human CD11b mAb Leu-15 (Becton Dickinson Immunocytometry Systems, Mountain View, CA) and PerCP-

1. Abbreviations used in this paper: $\mathrm{CRP}, \mathrm{C}$-reactive protein; $\mathrm{FU}$, fluorescence units; HCAEC, human coronary artery endothelial cells; HMVEC-L, human lung microvascular endothelial cells; sL-selectin, soluble L-selectin. 
conjugated mouse anti-human CD45 mAb 2D1 (Becton Dickinson). Appropriately labeled, class-matched irrelevant mouse $\mathrm{IgG}_{1}$ was used as a negative control for each staining. The following murine mAbs were used in neutrophil-endothelial cell adhesion assays: antiL-selectin mAb DREG-56 (IgG I $_{1}$ PharMingen) at $20 \mu \mathrm{g} / \mathrm{ml}(18,19)$; anti-E-selectin mAb ENA-2 $\left(\operatorname{IgG}_{1}\right.$, purified $\mathrm{F}\left(\mathrm{ab}^{\prime}\right)_{2}$ fragments, Monosan, Uden, The Netherlands) at $10 \mu \mathrm{g} / \mathrm{ml}$ (20), and anti-CD18 $\mathrm{mAb} \operatorname{L130}\left(\mathrm{IgG}_{1}\right.$, Becton Dickinson) at $10 \mu \mathrm{g} / \mathrm{ml}$. The irrelevant $\mathrm{mAb}$ MOPC-21 ( $\mathrm{IgG}_{1}$, PharMingen) at $20 \mu \mathrm{g} / \mathrm{ml}$ was used as a negative control.

Human CRP was obtained from Calbiochem-Novabiochem Corp. (La Jolla, CA). Purity of the protein was ascertained as a single silverstained protein band of $22 \mathrm{kD}$. Peptides corresponding to amino acid sequences 77-82 (Val-Gly-Gly-Ser-Glu-Ile), 174-185 (Ile-Tyr-Leu-GlyGly-Pro-Phe-Ser-Pro-Asn-Val-Leu), and 201-206 (Lys-Pro-Gln-LeuTrp-Pro) were purchased from Sigma Chemical Co. (St. Louis, MO). Purity of the peptides, as analyzed by the manufacturer, was $99 \%$. The peptides were stored in distilled water at $-20^{\circ} \mathrm{C}$. Goat antihuman CRP antiserum and LPS (Escherichia coli O111:B4) were obtained from Sigma Chemical Co.

Compound KD-IX-73-4 ( $N$-L-(2-hydroxyamino-carbonyl)methyl)4-methylpentanoyl)-L-3-(2'-naphthyl)-alanyl-L-alanine amide), which inhibits shedding of L-selectin (21), was a gift from Dr. Takashi Kei Kishimoto (Boehringer Ingelheim Pharmaceuticals, Ridgefield, CT), and was prepared in DMSO (final concentration: $66 \mu \mathrm{mol} / \mathrm{ml}$ ) and stored at $-20^{\circ} \mathrm{C}$

Whole blood incubation. Venous blood $(10 \mathrm{ml}$, anticoagulated with sodium heparin, $50 \mathrm{U} / \mathrm{ml}$ ) was obtained by antecubital venipuncture from nonsmoking healthy volunteers (male and female, 32-54 yr) who had not taken any drugs for at least $10 \mathrm{~d}$ before the experiments. Informed consent was obtained from each volunteer, and the protocol was approved by the Clinical Research Committee. White blood cell counts were between 5,000 and 9,000 cells/ $\mu$ l. Whole blood aliquots were transferred to polypropylene centrifuge tubes, placed on a rotator, and incubated with CRP or one of the CRP peptides (3.1-200 $\mu \mathrm{g} / \mathrm{ml}$ ) for $30 \mathrm{~min}$ at $37^{\circ} \mathrm{C}, 95 \%$ air $/ 5 \% \mathrm{CO}_{2}$. Preliminary experiments showed that the maximum effects that can be observed with CRP were achieved within 30 min of preincubation. In additional experiments, aliquots of blood were preincubated for $10 \mathrm{~min}$ with various concentrations of KD-IX-73-4 before addition of CRP or CRP peptides.

Flow cytometry analysis. Resting and treated neutrophils in whole blood were incubated with saturating concentration of fluorescent dye-conjugated anti-human L-selectin, anti-human CD11b, or antihuman $\mathrm{CD} 45 \mathrm{mAb}$ for $30 \mathrm{~min}$ at $22^{\circ} \mathrm{C}$, erythrocytes were lysed, and leukocytes were fixed with $2 \mathrm{ml}$ of a lysing medium (FACS ${ }^{\circledR}$ Lysing Solution; Becton Dickinson). The samples were then centrifuged, washed, and resuspended in PBS containing $0.1 \%$ sodium azide. Negative controls were obtained by omitting monoclonal antibodies. Nonspecific binding was evaluated by using appropriately labeled mouse $\mathrm{IgG}_{1}$. Single-color immunofluorescence staining was analyzed by a cytofluorometer (FACScan ${ }^{\circledR}$; Becton Dickinson) with Lysis II software. Data from 10,000 events per sample were acquired. Antibody binding was determined as mean fluorescence intensity after gating for neutrophils by their characteristic forward and side scatter properties. The results are presented as relative fluorescence units $(\mathrm{RFU}): R F U=\left(F U_{\text {experimental }}-F U_{\text {isotype }}\right) \times 100 /\left(F U_{\text {control }}-F U_{\text {isotype }}\right)$, where $\mathrm{FU}_{\text {experimental }}$ and $\mathrm{FU}_{\text {control }}$ are the $\mathrm{CD} 11 \mathrm{~b}$ or L-selectin fluorescence intensity of treated cells and cells cultured in medium only, respectively, and $\mathrm{FU}_{\text {isotype }}$ is the fluorescence intensity of class-matched irrelevant antibody. Likewise, in additional experiments, suspensions of isolated neutrophils were incubated under identical conditions with the conjugated antibodies, and fluorescence was assessed as described above.

Isolation and treatment of neutrophil granulocytes. Neutrophil granulocytes were isolated from peripheral blood by centrifugation through Ficoll-Hypaque gradients (Pharmacia Diagnostics AB, Uppsala, Sweden), sedimentation through dextran $(3 \%$, wt/vol), and hy- potonic lysis of erythrocytes. The resultant cell preparation contained $>97 \%$ neutrophils. Neutrophils were suspended in a modified HBSS (in mmol/liter: $\mathrm{NaCl}, 145 ; \mathrm{K}_{2} \mathrm{PO}_{4}, 10 ; \mathrm{CaCl}_{2}, 1.4 ; \mathrm{MgCl}_{2}, 1.2$; glucose, 10; and bovine serum albumin, $250 \mu \mathrm{g} / \mathrm{ml}, \mathrm{pH}$ 7.4). The experiments were carried out in $1.5 \mathrm{ml}$ polypropylene tubes. Neutrophils $\left(5 \times 10^{6}\right.$ cells $/ \mathrm{ml}$ ) were incubated in HBSS with CRP or CRP peptides (3.1$200 \mu \mathrm{g} / \mathrm{ml}$ ) for $30 \mathrm{~min}$ at $37^{\circ} \mathrm{C}$. Then the cells were pelleted, and the supernatants were collected for further analysis.

Enzymatic activity of supernatants from treated neutrophils. Lactate dehydrogenase (8), $\beta$-glucuronidase (8), lysozyme (8), and gelatinase (22) were assayed as described. Enzyme release was determined as the percentage of total enzyme units released from neutrophils treated with $0.1 \%$ Triton $\mathrm{X}-100$.

Neutrophil-endothelial cell attachment assay. Normal human coronary artery endothelial cells (HCAEC) and lung microvascular endothelial cells (HMVEC-L) were obtained from Clonetics Corp. (San Diego, CA) and grown in endothelial cell growth medium containing $5 \%$ FBS and supplemented with human recombinant epidermal growth factor $(10 \mathrm{ng} / \mathrm{ml})$, hydrocortisone $(1 \mathrm{mg} / \mathrm{ml})$, gentamycin $(50 \mathrm{mg} / \mathrm{ml})$, amphotericin B $(50 \mu \mathrm{g} / \mathrm{ml})$, and bovine brain extract $(3 \mathrm{mg} / \mathrm{ml})$. HCAEC or HMVEC-L (passages 5 and 6 ) were seeded into 96-well microplates and grown to confluence. Cell monolayers were carefully washed, overlaid with $250 \mu \mathrm{l}$ RPMI 1640 medium containing $10 \%$ FBS, and stimulated with LPS $(1 \mu \mathrm{g} / \mathrm{ml})$ for $6-8 \mathrm{~h}$ at $37^{\circ} \mathrm{C}$ in a $5 \%$ $\mathrm{CO}_{2}$ atmosphere. The cells were then washed three times with $200 \mu \mathrm{l}$ RPMI 1640 medium containing $10 \%$ FBS and $2 \times 10^{5}{ }^{51} \mathrm{Cr}$-labeled neutrophils in $100 \mu \mathrm{l}$ were added. In another set of experiments, LPSactivated HCAEC were incubated for 15 min with ENA-2 or MOPC$21 \mathrm{mAbs}$ before addition of neutrophils. The mAb reactive with E-selectin was also added back to the neutrophil suspensions so that $\mathrm{mAb}$ ENA-2 was present throughout the assay. Radiolabeled neutrophils were incubated with DREG-56, L130, or MOPC-21 mAb for $15 \mathrm{~min}$ at $37^{\circ} \mathrm{C}$ before addition to the endothelial cell monolayers. After incubation of endothelial cells with neutrophils for $30 \mathrm{~min}$ at 4 or $37^{\circ} \mathrm{C}$ on an orbital shaker at $90 \mathrm{rpm}$, loosely adherent or unattached neutrophils were washed three times with RPMI 1640 medium containing $10 \%$ FBS, and the endothelial monolayer plus the adherent neutrophils were lysed in $200 \mu \mathrm{l}$ of $0.1 \mathrm{~mol} / \mathrm{liter} \mathrm{NaOH}$. The number of neutrophils in each experiment was estimated from the radioactivity of a control sample. Inhibition of neutrophil attachment was calculated using the level of attachment to unstimulated endothelial cells as the baseline, and the level of attachment of LPS-stimulated endothelial cells as the maximal value. Neither treatment of HCAEC with any of the antibody used in these studies nor carrying out the assays at 4 or $37^{\circ} \mathrm{C}$ altered the integrity of viable endothelial monolayers.

$s L$-Selectin ELISA. Soluble L-selectin (sL-selectin) was quantitated in the supernatant of CRP-treated neutrophils by a specific ELISA (Bender MedSystems, Vienna, Austria). The detection limit of the assay was $0.4 \mathrm{ng} / \mathrm{ml}$. Intraassay coefficient of variation was $4.6 \%$ at the midpoint $(3.2 \mathrm{ng} / \mathrm{ml})$ of the standard curve. There was no cross-reactivity with CRP or any of the CRP peptides studied.

Statistical analysis. Results are expressed as means \pm SEM. Statistical comparisons were made by ANOVA using ranks (Kruskal-Wallis test) followed by Dunn's multiple contrast hypothesis test to identify differences between various treatments, or by the Wilcoxon signed rank test and Mann-Whitney U test for paired and unpaired observations, respectively. $P$ values $<0.05$ were considered significant for all tests.

\section{Results}

CRP and peptides derived from CRP attenuate adhesion of neutrophils to LPS-stimulated endothelial cells. To study whether CRP or CRP peptides could affect neutrophil adhesion, we analyzed the attachment of neutrophils to HMVEC-L and HCAEC under nonstatic conditions. Only a few neutrophils were able to bind to unstimulated endothelial cells. However, 


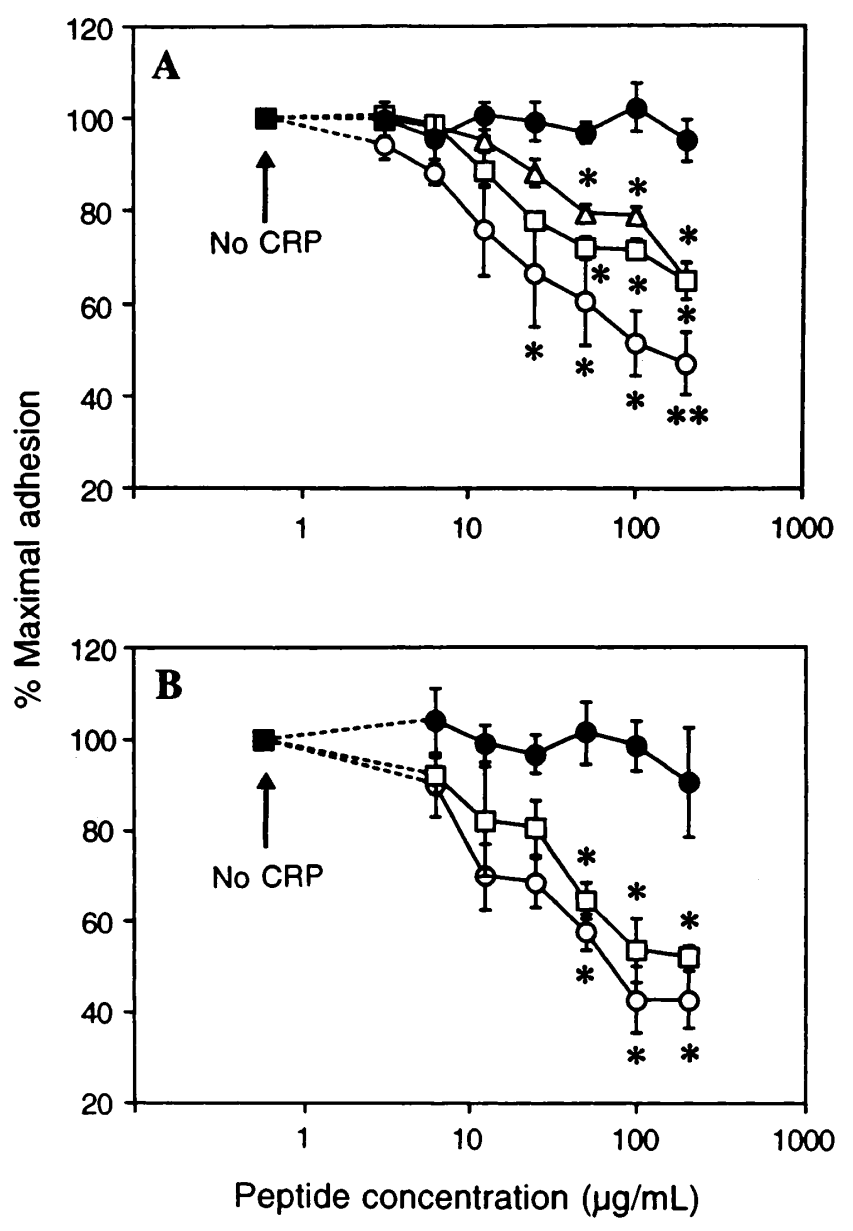

Figure 1. Effect of CRP and peptides derived from CRP on neutrophil attachment to human coronary artery $(A)$ and pulmonary microvascular $(B)$ endothelial cells. Confluent endothelial cell monolayers cultured for $6-8 \mathrm{~h}$ with $1 \mu \mathrm{g} / \mathrm{ml}$ LPS were used for neutrophil adhesion assays. Neutrophil granulocytes were incubated with CRP (open circles), peptide 77-82 (closed circles), peptide 174-185 (open triangles), or peptide 201-206 (open squares) for $30 \mathrm{~min}$ at $37^{\circ} \mathrm{C}$ before addition to endothelial cells. Adherence of neutrophils to unstimulated endothelium was determined, subtracted from the neutrophil adherence to stimulated endothelium, then expressed as a percentage of net adherence of neutrophils to LPS-stimulated endothelial monolayers. Neutrophil adhesion to unstimulated and LPSstimulated HCAEC was $1.3 \pm 0.5 \times 10^{4}$ and $4.2 \pm 1.3 \times 10^{4}$ cells per well, respectively $(n=3)$. Neutrophil adhesion to unstimulated and LPS-stimulated HMVEC-L was $0.6 \pm 0.1 \times 10^{4}$ and $4.3 \pm 0.6 \times 10^{4}$ cells per well, respectively $(n=3)$. Values are expressed as mean \pm SEM of three experiments in duplicate using neutrophils from different donors. $* P<0.05$; ** $P<0.01$; *** $P<0.001$ vs. positive control (No CRP).

when endothelial cells were activated with LPS $(1 \mu \mathrm{g} / \mathrm{ml})$, on average 3.3- and 6.8-fold more neutrophils adhered to treated than to untreated HCAEC and HMVEC-L, respectively (Fig. 1). Preincubation of neutrophils with CRP inhibited neutrophil adhesion to LPS-activated HCAEC and HMVEC-L in a concentration-dependent manner with apparent $\mathrm{IC}_{50}$ values of 20 and $22 \mu \mathrm{g} / \mathrm{ml}$, respectively (Fig. 1). No significant decreases in adhesion could be detected when untreated neutrophils were added to HCAEC cultured with LPS in the presence of
$200 \mu \mathrm{g} / \mathrm{ml}$ CRP $\left(4.2 \pm 1.3 \times 10^{4}\right.$ cells vs. $3.9 \pm 1.1 \times 10^{4}$ cells attached per well, $n=3)$. Preincubation of neutrophils with peptide 174-185 or 201-206 also attenuated neutrophil adherence to HCAEC, albeit these peptides showed a weaker inhibitory effect than CRP (Fig. $1 A$ ). Similar results were obtained with peptide 201-206 using HMVEC-L (Fig. 1 B). In contrast, peptide 77-85 did not inhibit neutrophil adhesion (Fig. 1).

Preincubation of neutrophils with anti-CRP antiserum did not affect their adhesion to HCAEC. However, when CRP was preincubated with $\mathrm{CRP}$ antiserum for $20 \mathrm{~min}$ at $37^{\circ} \mathrm{C}$ before addition to neutrophils, neutrophil adhesion was nearly completely restored (number of neutrophils attached to LPSactivated HCAEC: medium only, $4.2 \pm 1.3 \times 10^{4}$ cells per well; CRP, $2.6 \pm 0.7 \times 10^{4}$ cells per well; anti-CRP antiserum plus CRP, $4.0 \pm 1.4 \times 10^{4}$ cells per well, $n=6$ ).

Inhibition of L-selectin-mediated neutrophil adhesion to activated endothelial cells by CRP. Since multiple receptors are involved in neutrophil adhesion to LPS-stimulated endothelium even under nonstatic conditions (23), we assayed the contribution of L-selectin, E-selectin, and CD18 to the binding interaction and studied the possibility that CRP could affect E-selectin or CD18 function by using function-blocking mAbs. The binding assays were carried out at $37^{\circ} \mathrm{C}$ as well as at $4^{\circ} \mathrm{C}$, where L-selectin shedding and CD18-dependent adhesion are minimal (23).

At $37^{\circ} \mathrm{C}$, a significant proportion of neutrophil-HCAEC attachment was blocked by mAb binding to E-selectin $(40 \pm 8 \%$, $n=3)$, L-selectin $(47 \pm 6 \%)$, or CD18 (22 $2 \%$ ) (Fig. $2 A)$. The combination of these mAbs inhibited the binding of neutrophils by $80-86 \%$ (Fig. $2 A$ ). Adhesion of neutrophils treated with CRP $(200 \mu \mathrm{g} / \mathrm{ml})$ and anti-L-selectin $\mathrm{mAb}$ was similar to those observed with neutrophils treated with CRP or antiL-selectin $\mathrm{mAb}$ alone (Fig. $2 \mathrm{~B}$ ). Combination of CRP with either anti-E-selectin or anti-CD18 mAb resulted in inhibition of neutrophil binding similar to those observed with combinations of anti-L-selectin $\mathrm{mAb}$ and anti-E-selectin or anti-CD18 mAb, respectively (Fig. $2 A$ ). Combining CRP, anti-E-selectin, and anti-CD18 mAbs blocked $\sim 85 \%$ of adhesion. Thus, $\mathrm{CRP}$ acts in concert with anti-E-selectin and anti-CD18 mAb, but not with anti-L-selectin $\mathrm{mAb}$, to inhibit neutrophil attachment to LPS-activated HCAEC, and in this assay system, L-selectin, E-selectin, and CD18 in combination can account for nearly all neutrophil attachment.

At $4^{\circ} \mathrm{C}$, neutrophil adhesion was inhibited by anti-L-selectin $\mathrm{mAb}(54 \pm 3 \%, n=3)$ and anti-E-selectin $\mathrm{mAb}(55 \pm 5 \%)$,

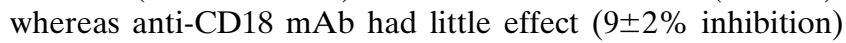
(Fig. 2 B). Again, combining these mAb blocked $\sim 80 \%$ of adhesion. CRP in combination with anti-L-selectin $\mathrm{mAb}$ produced inhibition of neutrophil adhesion similar to that observed with CRP or anti-L-selectin $\mathrm{mAb}$ alone (Fig. $2 \mathrm{~B}$ ). The inhibitory actions of CRP and anti-E-selectin or anti-CD18 $\mathrm{mAb}$ were additive, and did not differ from those observed with a combination of anti-L-selectin and anti-E-selectin or anti-CD18 mAb, respectively (Fig. $2 \mathrm{~B}$ ). The combination of CRP with anti-E-selectin and anti-CD18 mAbs inhibited 78$85 \%$ of neutrophil adhesion. Assayed at either 4 or $37^{\circ} \mathrm{C}$, qualitatively similar results were obtained when peptide $174-185$ or 201-206 was combined with anti-E-selectin or anti-CD18 $\mathrm{mAb}$ (data not shown), and the control mAb (MOPC-21) gave results similar to medium alone (Fig. 2, $A$ and $B$ ).

KD-IX-73-4 prevents the effects of CRP and peptides 174 185 and 201-206 on neutrophil-endothelial cell attachment. To 


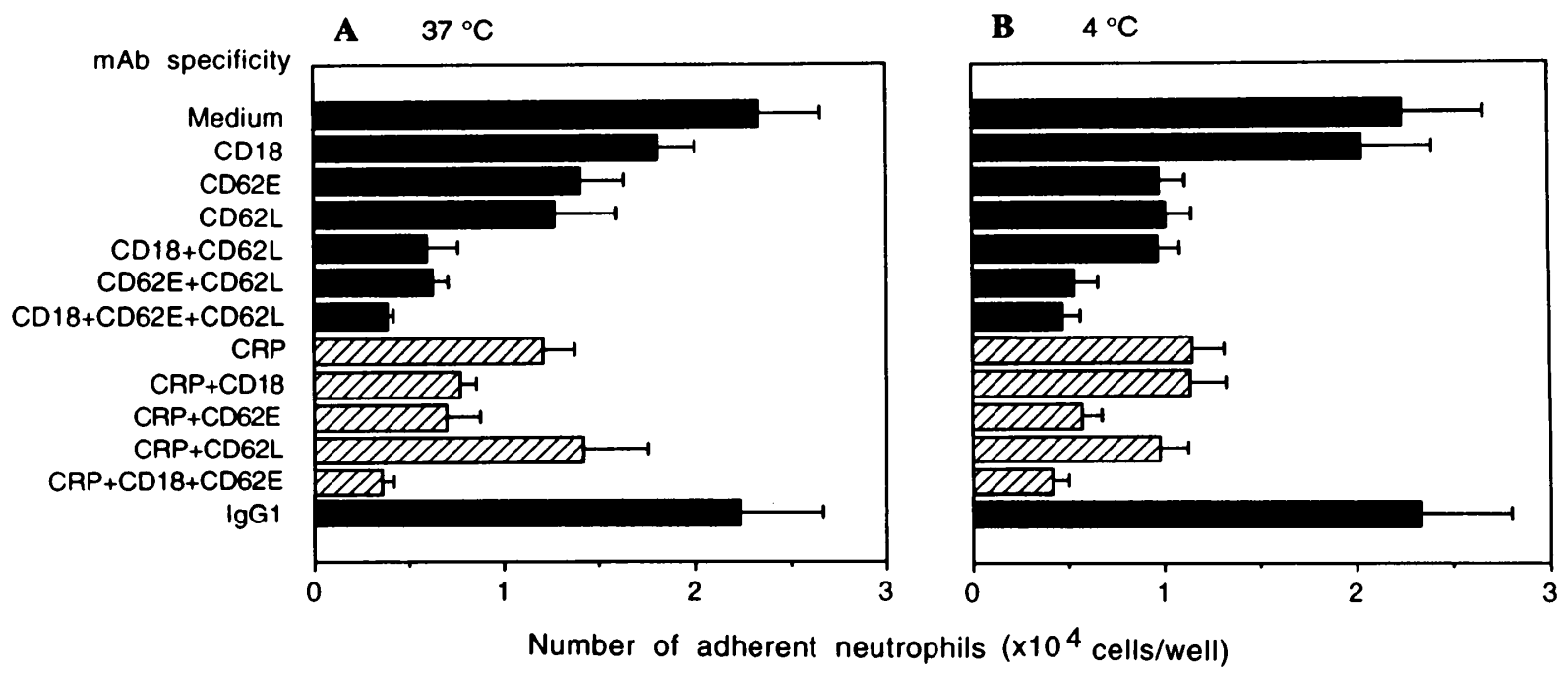

Figure 2. Inhibition of neutrophil binding to endothelial cells by anti-E-selectin, anti-L-selectin, and anti-CD18 mAbs, and CRP. Confluent HCAEC monolayers were activated for $6 \mathrm{~h}$ with $1 \mu \mathrm{g} / \mathrm{ml}$ LPS. Neutrophils and HCAEC were treated with CRP $(200 \mu \mathrm{g} / \mathrm{ml}) \mathrm{or}$ the indicated $\mathrm{mAbs}$ before and during the assay. Neutrophils were incubated with endothelial cells for $30 \mathrm{~min}$ at $37(A)$ or $4^{\circ} \mathrm{C}(B)$. Neutrophil adhesion to unstimulated HCAEC was $0.57 \pm 0.08 \times 10^{4}$ and $0.34 \pm 0.05 \times 10^{4}$ cells per well at 37 and $4^{\circ} \mathrm{C}$, respectively $(n=3)$. The irrelevant $\mathrm{mAb}$ MOPC-21 $\left(\mathrm{IgG}_{1}\right)$ was used as a negative control. Results are expressed as mean \pm SEM of three experiments using neutrophils from different donors.

study further the L-selectin-dependent component of neutrophil-endothelial attachment, we examined whether inhibition of L-selectin shedding would alter the actions of CRP or CRPderived peptides on adhesion of neutrophils to HCAEC. Pretreatment of neutrophils with the metalloprotease inhibitor KD-IX-73-4 (44 nmol/ml) before challenging them with CRP or peptides $174-185$ or $201-206$ (each at $200 \mu \mathrm{g} / \mathrm{ml}$ ) almost completely restored neutrophil binding to HCAEC (Fig. 3). KD-IX-73-4 alone did not affect neutrophil adhesion to activated endothelial cells (Fig. 3).

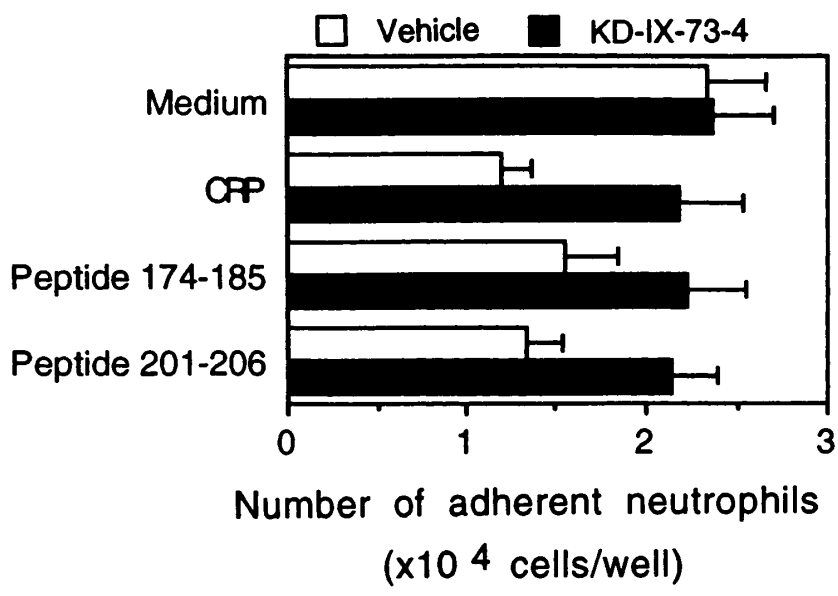

Figure 3. KD-IX-73-4 prevents the effects of CRP on neutrophilendothelial cell attachment. Chromium-51-labeled neutrophils were incubated for $15 \mathrm{~min}$ with KD-IX-73-4 (44 nmol/ $\mathrm{ml}$, solid columns $)$ or its vehicle (open columns), and challenged for 30 min with CRP, peptide $174-185$, or $201-206$ (all at $200 \mu \mathrm{g} / \mathrm{ml}$ ) at $37^{\circ} \mathrm{C}$ before addition to LPS-activated HCAEC. The adhesion assay was performed at $37^{\circ} \mathrm{C}$. Neutrophil binding to unstimulated HCAEC was $0.57 \pm 0.08 \times 10^{4}$ cells per well. Values are shown as mean \pm SEM of three experiments in duplicate using neutrophils from different donors.
L-Selectin expression on neutrophils is downregulated by $C R P$ and peptides derived from CRP. We next determined whether the effect of CRP and CRP peptides on neutrophil adhesiveness resulted from diminished expression of L-selectin. Flow cytometry analysis of whole blood treated with CRP showed that the neutrophil surface expression of L-selectin was downregulated by CRP in a concentration-dependent fashion with an apparent $\mathrm{IC}_{50}$ concentration of $24 \mu \mathrm{g} / \mathrm{ml}$ (Fig. 4). CRP showed a stronger effect than peptides 174-185 and 201-206, while peptide 77-82 had no effect on L-selectin expression

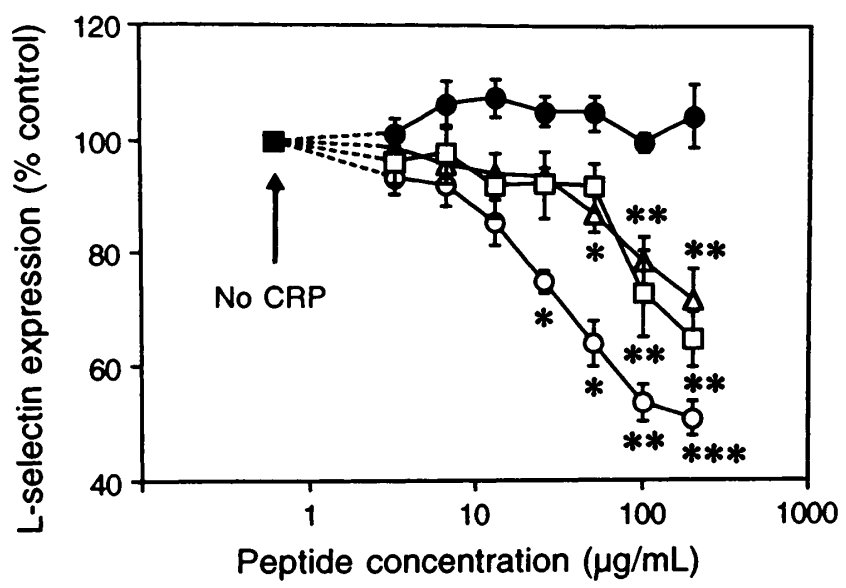

Figure 4. Concentration-dependent effect of CRP and CRP-derived peptides on surface expression of L-selectin by neutrophils. Aliquots of whole blood were incubated with CRP (open circles), peptide77-82 (closed circles), peptide 174-185 (open triangles), or peptide 201-206 (open squares) for $30 \mathrm{~min}$ at $37^{\circ} \mathrm{C}$. L-Selectin expression is presented as percentage of control, i.e., mean fluorescence-intensity of neutrophils cultured in medium only for $30 \mathrm{~min}$. Values are expressed as mean \pm SEM for five to six experiments using blood from different donors. $* P<0.05$; $* * P<0.01$ vs. positive control (No CRP). 


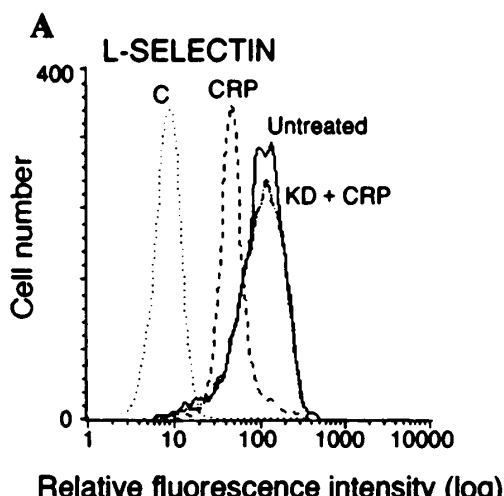

Relative fluorescence intensity (log)

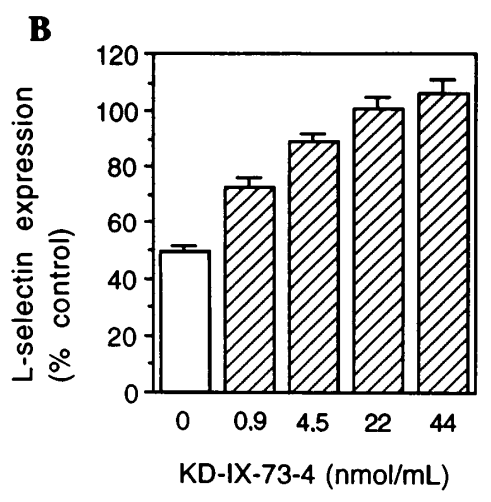

Figure 5. KD-IX-73-4 inhibits downregulation of neutrophil surface expression of L-selectin. ( $A$ ) Aliquots of whole blood were preincubated for $15 \mathrm{~min}$ with KD-IX-73-4 (44 $\mathrm{nmol} / \mathrm{ml})$, and challenged for $30 \mathrm{~min}$ with CRP $(200 \mu \mathrm{g} / \mathrm{ml})$ at $37^{\circ} \mathrm{C}$. In a representative histogram, the basal expression of the cell surface antigen (Untreated) and the negative control $(C)$ immunostaining is also shown. (B) Concentration-dependent inhibition of CRP-induced downregulation of L-selectin expression. Aliquots of whole blood were preincubated for 15 min with various concentrations of KD-IX-73-4 (hatched columns) or its vehicle (open column), and challenged for $30 \mathrm{~min}$ with CRP $(200 \mu \mathrm{g} / \mathrm{ml})$ at $37^{\circ} \mathrm{C}$. Values represent the mean \pm SEM obtained in duplicate determination for each sample. The results are representative of three independent experiments.

(Fig. 4). Neither CRP nor any of the CRP peptides studied affected basal expression of L-selectin when the experiments were performed at $4^{\circ} \mathrm{C}$ (data not shown). Anti-CRP antiserum almost completely prevented the effect of CRP on L-selectin expression (mean fluorescence intensity for L-selectin: medium only, 84 \pm 7 ; CRP, $200 \mu \mathrm{g} / \mathrm{ml}, 47 \pm 4$; anti-CRP antiserum plus CRP, $80 \pm 6, n=6$ ). Qualitatively and quantitatively similar effects on L-selectin expression were seen after incubation of isolated neutrophils with CRP or CRP peptides (data not shown).

KD-IX-73-4 prevents downregulation of neutrophil L-selectin expression elicited by CRP and peptides 174-185 and 201206. Preincubation of whole blood aliquots with KD-IX-73-4 inhibited CRP-induced downregulation of L-selectin expression in a concentration-dependent fashion with an apparent $\mathrm{IC}_{50}$ concentration of $\sim 1.6 \mathrm{nmol} / \mathrm{ml}$ (Fig. 5). Similarly, the effects of peptides 174-185 and 201-206 were also completely inhibited by $44 \mathrm{nmol} / \mathrm{ml} \mathrm{KD-IX-73-4} \mathrm{(data} \mathrm{not} \mathrm{shown).} \mathrm{KD-IX-}$ 73-4 did not affect the characteristic forward- and side-light scatter profiles of neutrophils challenged with CRP or CRP peptides (data not shown).

Effect of CRP and peptides derived from CRP on neutrophil activation. Since L-selectin is rapidly downregulated from the surface of neutrophils upon cell activation, we investigated the possibility that CRP or CRP-derived peptides could activate neutrophils. We analyzed neutrophil surface expression of CD11b and CD45, which is upregulated upon activation and degranulation. CRP at a concentration of $200 \mu \mathrm{g} / \mathrm{ml}$ failed to
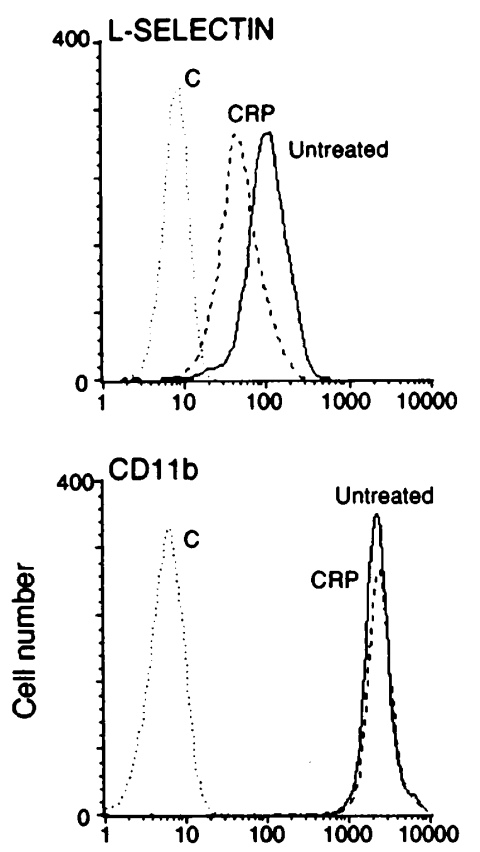

Figure 6. Effect of CRP on neutrophil surface expression of L-selectin, CD11b, and CD45. Aliquots of whole blood were incubated for $30 \mathrm{~min}$ in the presence of $200 \mu \mathrm{g} / \mathrm{ml} \mathrm{CRP} \mathrm{at}$ $37^{\circ} \mathrm{C}$. In each histogram, the basal expression of the cell surface antigen (Untreated) and the negative control (C) of immunostaining is also shown. One representative experiment $(n=6)$ is shown.

modify baseline expression of CD11b or CD45 upon $30 \mathrm{~min}$ of whole blood treatment (Fig. 6). Similar results were obtained with CRP-derived peptides studied (data not shown).

Incubation of isolated neutrophils with CRP or any of the CRP peptides for $30 \mathrm{~min}$ did not induce a significant release of $\beta$-glucuronidase (a marker for azurophil granules), lysozyme (a marker for specific plus azurophil granules), or gelatinase (a marker for tertiary granules) (Table I). As a positive control, neutrophils challenged with platelet-activating factor secreted high amounts of gelatinase (Table I). Lactate dehydrogenase release never exceeded $2 \%$ of the total cell content, and was similar in the absence and presence of CRP or CRP peptides (data not shown), indicating that cellular integrity was not affected.

Shedding of $L$-selectin by CRP and peptides derived from $C R P$. To determine whether CRP and CRP peptides exert their inhibitory effect on neutrophil-endothelial cell adhesion by the cleavage and shedding of L-selectin, we measured sLselectin in the cell-free supernatants of neutrophils incubated with CRP or CRP peptides for $30 \mathrm{~min}$. CRP at $200 \mu \mathrm{g} / \mathrm{ml}$ produced more than a threefold increase in sL-selectin concentrations, which can be prevented by anti-CRP antiserum (Fig. 7). The maximum amount of sL-selectin detected after CRP was $\sim 76 \%$ of the amount measured in the supernatant from neutrophils challenged with platelet-activating factor (Fig. 7). 
Table I. Granule Enzyme Release from Human Neutrophils by CRP and Peptides Derived from CRPs

\begin{tabular}{llcc}
\hline & \multicolumn{3}{c}{ Enzyme release } \\
\cline { 2 - 4 } & Gelatinase & B-Glucuronidase & Lysozyme \\
\hline Control & $18.7 \pm 1.6$ & $2.3 \pm 0.4$ & $6.0 \pm 0.8$ \\
PAF & $57.0 \pm 5.6^{*}$ & $2.5 \pm 0.5$ & $6.2 \pm 0.9$ \\
CRP & $20.6 \pm 2.0$ & $2.7 \pm 0.4$ & $5.5 \pm 0.7$ \\
Peptide 77-82 & $21.4 \pm 1.4$ & $2.3 \pm 0.4$ & $6.2 \pm 0.8$ \\
Peptide 174-185 & $24.9 \pm 0.9$ & $2.2 \pm 0.3$ & $5.8 \pm 1.5$ \\
Peptide 201-206 & $22.7 \pm 2.6$ & $2.3 \pm 0.5$ & $5.7 \pm 1.1$ \\
& & &
\end{tabular}

Values are expressed as percentage of total cellular enzyme activity released by neutrophils to the culture medium after incubation with CRP $(200 \mu \mathrm{g} / \mathrm{ml})$, CRP-derived peptides $(200 \mu \mathrm{g} / \mathrm{ml})$, or platelet-activating factor $(P A F, 1 \mu \mathrm{mol} / \mathrm{l})$ for $30 \mathrm{~min}$ at $37^{\circ} \mathrm{C}$. Total cell enzyme activity was measured in unstimulated neutrophils disrupted by treatment with $0.1 \%$ Triton X-100. Values are means \pm SEM of four independent experiments. $* P<0.05$ compared to control.

Lower amounts of sL-selectin were detected in the supernatant medium of neutrophils incubated with peptides 174-185 and 201-206 at $200 \mu \mathrm{g} / \mathrm{ml}$ concentration (Fig. 7), corresponding to their potency to downregulate surface expression of L-selectin. In contrast, peptide 77-82 did not increase sL-selectin concentration (Fig. 7).

\section{Discussion}

We describe in this report that a novel mechanism by which CRP and CRP-derived peptides 174-185 and 201-206 may affect the inflammatory response is the modulation of adhesion of neutrophils to the endothelium. CRP or CRP-derived peptides 174-185 and 201-206 acting on neutrophils diminish attachment of resting neutrophils to LPS-stimulated endothelial cells via downregulation and shedding of L-selectin from the surface of neutrophils.

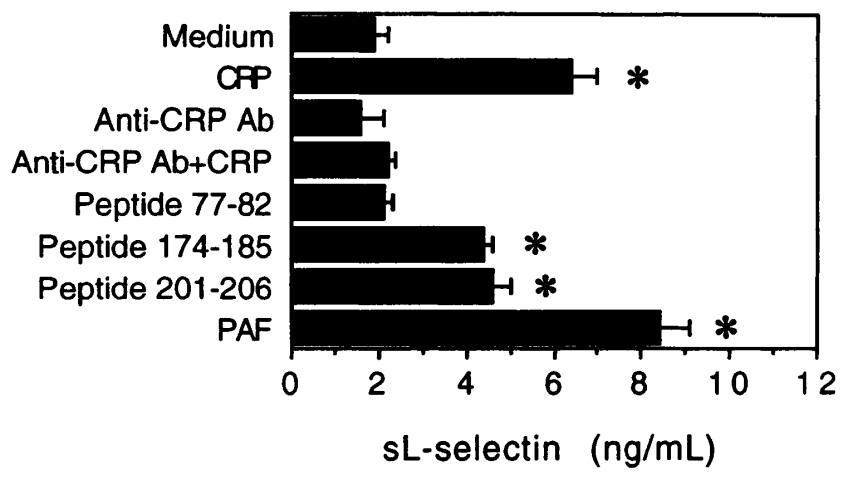

Figure 7. CRP and CRP-derived peptides induce shedding of L-selectin from neutrophils. Isolated neutrophils were incubated for $30 \mathrm{~min}$ in the presence of CRP $(200 \mu \mathrm{g} / \mathrm{ml})$, CRP plus anti-human CRP antiserum (Anti-CRP Ab), peptide 77-82, 174-185, or 201-206 (all at $200 \mu \mathrm{g} / \mathrm{ml})$, or platelet-activating factor $(P A F, 1 \mu \mathrm{mol} / \mathrm{l})$ at $37^{\circ} \mathrm{C}$. Supernatant fluids were collected and tested for sL-selectin by a specific ELISA. Values are means \pm SEM for three donor cell preparations. $* P<0.05$ compared to control.
The neutrophil-endothelial cell attachment assay was used to study the first step of neutrophil migration. To simulate blood flow, the experiments were performed under nonstatic conditions (24). In agreement with results previously reported by other authors (23-25), mAbs against L-selectin, E-selectin, and CD18 each partially inhibited the adhesion of neutrophils to $\mathrm{HCAEC}$ at $37^{\circ} \mathrm{C}$, whereas together they inhibited $80-86 \%$ of neutrophil adhesion. These results suggest that each of these adhesion molecules function independently and interact in a cooperative fashion to promote optimal neutrophil adhesion to HCAEC. To our knowledge, this study demonstrates for the first time that CRP can effectively attenuate the neutrophil attachment to LPS-activated human endothelial cells. This inhibition can be attributed to an effect of CRP on neutrophils rather than endothelial cells, as no significant decreases in neutrophil attachment were observed after culture of endothelial cells with LPS in the presence of CRP. Indeed, this study provides three lines of evidence indicating that CRPinduced inhibition of neutrophil adhesion to endothelial cells is predominantly attributable to the shedding of L-selectin. First, the shedding of L-selectin correlated with reduced neutrophil adhesion. Second, CRP or a function-blocking antiL-selectin $\mathrm{mAb}$ resulted in similar reductions in neutrophil adhesion to HCAEC. Furthermore, the inhibitory actions of $\mathrm{CRP}$ and anti-L-selectin $\mathrm{mAb}$ were not additive, as assayed at both 37 and $4^{\circ} \mathrm{C}$, where the L-selectin-dependent component of adhesion is larger (23, and this study). On the other hand, the inhibition with CRP was additive with anti-E-selectin and anti-CD18 mAbs, and did not differ from the inhibition observed when anti-L-selectin mAb was combined with antiE-selectin or anti-CD18 mAb. These findings would indicate that CRP neither affected E-selectin or CD18 function nor interfered with the E-selectin ligand or ICAM-1/ICAM-2 under our experimental conditions. Third, the L-selectin shedding inhibitor KD-IX-73-4 (21) at a concentration which completely inhibited CRP-induced downregulation of L-selectin expression also prevented the effects of CRP on neutrophil adhesion. The finding that CRP inhibits L-selectin-dependent adhesion may be of particular importance, because L-selectin may function as the initial attachment receptor to activated endothelium, as it occurs during both in vitro and in vivo rolling at physiologic flow rates $(14,15)$. CRP inhibited neutrophil adhesion to both HCAEC and HMVEC-L with similar potency, indicating its ability to attenuate neutrophil adhesion in different parts of the vasculature. Our observations would explain, at least in part, the mechanism by which CRP prevented leukocyte accumulation in experimental alveolitis $(6,7)$.

It has been suggested that the specific biologic function of CRP may reside in its subsequences, with the function expressed upon degradation of the parent protein (26). Indeed, three tuftsin-like (Thr-Lys-Pro-Arg) regions are present in the CRP molecule, and the corresponding three synthetic peptides have been found to stimulate neutrophil chemotaxis (26). Other peptides homologous to amino acid sequences within regions 77-82 and 201-206 have been reported to inhibit human neutrophil superoxide production and chemotaxis to several stimuli $(10,27)$ as well as eosinophil chemotaxis (28), whereas peptide 177-182 has been shown to augment cytokine production by alveolar monocytes/macrophages and to enhance their tumoricidal activity $(29,30)$. Extending previous findings with peptide 201-206 $(10,11,27)$, this study shows that this peptide can also effectively attenuate neutrophil at- 
tachment to both HCAEC and HMVEC-L. We were surprised that peptide 77-82, which was shown to inhibit neutrophil influx into alveoli after FMLP-induced inflammation in mice (11), even at a concentration as high as $200 \mu \mathrm{g} / \mathrm{ml}$, failed to affect neutrophil adhesion to endothelial cells. However, it should be noted that significant inhibition of neutrophil chemotaxis was only observed with peptide 77-82 concentrations higher than $200 \mu \mathrm{g} / \mathrm{ml}$ (11). Apart from differences in the assays used, the reason for this discrepancy is not readily apparent. Interestingly, peptide 177-182, which activates monocytes/ macrophages $(29,30)$, showed an inhibitory potency similar to that of peptide 201-206 in attenuating adhesion of neutrophils to HCAEC. These observations suggest cell-specific effects of CRP peptides on various inflammatory cells.

Our results indicated that larger concentrations of peptides 174-185 and 201-206 than native CRP were required to obtain a similar degree of inhibition. Even accounting for the fivefold molar difference between monomeric synthetic peptides and the pentameric native CRP, on a molar concentration basis, 100-150-fold more peptide than native CRP was needed to achieve a similar degree of inhibition of neutrophil attachment. It is likely that higher concentrations of CRP peptides may be needed to occupy the CRP receptor. Although we cannot rule out that CRP degradation occurred in these experimental conditions, the differences in the concentrations of native CRP and CRP peptides required to inhibit neutrophil attachment would not lend support to the hypothesis that the biologic functions of CRP may entirely reside in its degradation products (26).

Activation of neutrophils uniformly results in downregulation of L-selectin expression as well as in upregulation of both CD11b/CD18 and CD45 expression $(15,31,32)$. Within minutes of activation, leukocytes release L-selectin from their surface by a proteolytic cleavage just outside of the transmembrane domain $(15,33,34)$. However, neither native CRP nor CRP peptides at the concentrations studied affected basal expression of CD11b/CD18 and CD45, indicating that neutrophils were not activated. This notion is further supported by the failure of CRP and CRP peptides to induce release of granule enzymes. L-Selectin shedding not only occurs in response to cell activation, but also after treatment with a chemical cross-linker (35) or certain nonsteroidal antiinflammatory drugs (25). Although the biochemical and molecular nature of the proteolytic enzyme remains to be identified, it appears to be a constitutively active enzyme $(36,37)$. Formation of an appropriate three-dimensional structure of L-selectin near the membrane has been implicated in the regulation of this proteolytic process $(36,37)$. It is tempting to speculate that CRP and peptides 174-185 and 201-206 could activate this process. However, the enzyme(s) and signaling mechanisms that regulate the conformation of L-selectin in response to CRP or CRP peptides remain key areas of inquiry. Inactivation of the proteolytic enzyme by KD-IX-73-4 would block both activationdependent (21) and independent L-selectin shedding (this study). Our results indicate that downregulation of L-selectin expression is also due to the shedding of the molecule from the neutrophil surface, as quantitated by the soluble form of L-selectin in the cell-free supernatants of neutrophils cultured with CRP or CRP peptides. Although an inherent proteolytic activity of CRP itself on L-selectin cannot be completely ruled out, the observations that this phenomenon does not occur at $4{ }^{\circ} \mathrm{C}$ coupled with the demonstration of L-selectin shedding by
CRP peptides 174-185 and 201-206 would argue against this possibility.

The concentrations of CRP required in our in vitro experiments for the L-selectin shedding are below the peak plasma levels detected during the acute-phase response, suggesting that this event may also occur in vivo. However, it is difficult to establish a strict correlation between our in vitro observations and the in vivo behavior of CRP, which also depends on factors other than plasma concentrations, such as deposition at sites of tissue injury (38) and plasma metabolism (39). To our knowledge, no information is available on the local tissue or plasma levels of CRP peptides.

These experiments permit us to suggest a novel mechanism of action for CRP. This acute-phase protein may prevent migration of neutrophils into inflammatory sites by downregulating the neutrophil surface expression of L-selectin. This hypothesis rests on two separate lines of evidence: functional, at clinically relevant plasma concentrations native CRP inhibits L-selectin-dependent adhesion of neutrophils to LPS-activated endothelial cells; and phenotypic, at similar concentrations it selectively downregulates neutrophil expression of L-selectin expression without inducing cell activation. At the site of tissue injury or inflammation, CRP may undergo conformational changes, resulting in altered forms of CRP which may promote inflammation (40). On the other hand, considerable neutrophil-mediated degradation of CRP occurs at the same sites, resulting in peptides which either up- or downregulate leukocyte activity. Among these products, peptides 174-185 and 201-206 might also inhibit neutrophil migration, thereby contributing to demarcation of the inflammatory locus. These findings suggest that by diminishing leukocyte traffic into infected or injured tissues, native CRP and CRP peptides 174-185 and 201206 may be a major mechanism to attenuate or limit the inflammatory response.

\section{Acknowledgments}

The authors thank Dr. Takashi Kei Kishimoto for a generous gift of KD-IX-73-4 and helpful discussions, Dr. Éva Földes for critical reading of the manuscript, and the anonymous reviewers for their valuable suggestions.

This work was supported by grants from the Medical Research Council of Canada (MT-12573) and the University of Montréal.

\section{References}

1. Pepys, M.B. 1981. C-reactive protein fifty years on. Lancet. i:653-657.

2. Kushner, I. 1988. The acute phase response: an overview. Methods Enzymol. 163:373-383.

3. Müller, H., and J. Fehr. 1986. Binding of C-reactive protein to human polymorphonuclear leukocytes: evidence for association of binding sites with $\mathrm{F}_{\mathrm{c}}$ receptors. J. Immunol. 136:2202-2207.

4. Buchta, R., M. Pontet, and M. Fiedkin. 1987. Binding of C-reactive protein to human neutrophils. FEBS Lett. 211:165-168.

5. Kew, R.R., T.M. Hyers, and R.O. Webster. 1990. Human C-reactive protein inhibits neutrophil chemotaxis in vitro: possible implications for the adult respiratory distress syndrome. J. Lab. Clin. Med. 115:339-345.

6. Heuertz, R.M., C.A. Piquette, and R.O. Webster. 1993. Rabbits with elevated serum C-reactive protein exhibit diminished neutrophil infiltration and vascular permeability in C5a-induced alveolitis. Am. J. Pathol. 142:319-328.

7. Ahmed, N., R. Thorley, D. Xia, D. Samols, and R.O. Webster. 1996. Transgenic mice expressing rabbit C-reactive protein exhibit diminished vascular permeability and neutrophil infiltration in chemotactic factor-induced alveolitis. Am. J. Respir. Crit. Care Med. 153:1141-1147.

8. Filep, J., and E. Földes-Filep. 1989. Effects of C-reactive protein on human neutrophil granulocytes challenged with $N$-formyl-methionyl-leucyl-phenylalanine and platelet-activating factor. Life Sci. 44:517-524. 
9. Shephard, R.G., S.M. Beer, R. Anderson, A.F. Strachan, A.E. Nel, and F.C. de Beer. 1989. Generation of biologically active C-reactive protein peptides by a neutral protease on the membrane of phorbol myristate acetate-stimulated neutrophils. J. Immunol. 143:2974-2981.

10. Shephard, E.G., R. Anderson, O. Rosen, M.S. Myer, M. Friedkin, A.F. Strachan, and F.C. de Beer. 1990. Peptides generated from C-reactive protein by a neutrophil membrane protease. Amino acid sequence and effects of peptides on neutrophil oxidative metabolism and chemotaxis. J. Immunol. 145: $1469-1476$.

11. Heuertz, R.M., N. Ahmed, and R.O. Webster. 1996. Peptides derived from C-reactive protein inhibit neutrophil alveolitis. J. Immunol. 156:34123417.

12. Butcher, E.C. 1991. Leukocyte endothelial cell migration: three (or more) steps to specificity and diversity. Cell. 67:1033-1036.

13. Springer, T.A. 1994. Traffic signals for lymphocyte recirculation and leukocyte emigration: the multistep paradigm. Cell. 76:301-314.

14. Lawrence, M.B., and T.A. Springer. 1991. Leukocytes roll on a selectin at physiologic flow rates: distinction from and prerequisite for adhesion through integrins. Cell. 65:859-873.

15. Ley, K., P. Gaehtgens, C. Fennie, M.S. Singer, L.A. Lasky, and S.D. Rosen. 1991. Lectin-like cell adhesion molecule 1 mediates leukocyte rolling in mesenteric venules in vivo. Blood. 77:2553-2555.

16. Kishimoto, T.K., M.A. Jutila, E.L. Berg, and E.C. Butcher. 1989. Neutrophil Mac-1 and MEL-14 adhesion proteins inversely regulated by chemotactic factors. Science (Wash. DC). 245:1238-1241.

17. Jutila, M.A., L. Rott, E.L. Berg, and E.C. Butcher. 1989. Function and regulation of the neutrophil MEL-14 antigen in vivo: comparison with LFA-1 and Mac-1. J. Immunol. 143:3318-3324.

18. Kishimoto, T.K., M.A. Jutila, and E.C. Butcher. 1990. Identification of a human peripheral lymph node homing receptor: a rapidly down-regulated adhesion molecule. Proc. Natl. Acad. Sci. USA. 87:805-811.

19. Kishimoto, T.K., R.A. Warnock, M.A. Jutila, E.C. Butcher, C. Lane, D.C. Anderson, and C.W. Smith. 1991. Antibodies against human neutrophil LECAM-1 (LAM-1/Leu-8/DREG-56 antigen) and endothelial cell ELAM-1 inhibit a common CD18-independent adhesion pathway in vitro. Blood. 78 : 805-811.

20. Leeuwenberg, J.F.M., E.J.U. von Asmuth, T.M.A.A. Jeunhomme, and W.A. Buurman. 1990. IFN- $\gamma$ regulates the expression of the adhesion molecule ELAM-1 and IL-6 production by human endothelial cells in vitro. J. Immunol. 145:2110-2114.

21. Walcheck, B., J. Kahn, J.M. Fisher, B.B. Wang, R.S. Fisk, D.G. Payan, C. Feehan, R. Betageri, K. Darlak, A.F. Spatola, and T.K. Kishimoto. 1996. Neutrophil rolling altered by inhibition of L-selectin shedding in vitro. Nature (Lond.). 380:720-723.

22. Dewald, B., U. Bretz, and M. Baggiolini. 1982. Release of gelatinase from a novel secretory compartment of human neutrophils. J. Clin. Invest. 70: $518-525$.

23. Spertini, O., F.W. Luscinskas, G.S. Kansas, J.M. Munro, J.D. Griffin, M.A. Gimbrone, Jr., and T.F. Tedder. 1991. Leukocyte adhesion molecule-1 (LAM-1, L-selectin) interacts with an inducible endothelial cell ligand to support leukocyte adhesion. J. Immunol. 147:2565-2573.

24. Spertini, O., F.W. Luscinskas, M.A. Gimbrone, Jr., and T.F. Tedder. 1992. Monocyte attachment to activated human vascular endothelium in vitro is mediated by leukocyte adhesion molecule-1 (L-selectin) under non-static con- ditions. J. Exp. Med. 175:1789-1792.

25. Diaz-González, F., I. González-Alvaro, M.R. Campanero, F. Mollinedo, M.A. del Pozo, C. Muñoz, J.P. Pivel, and F. Sánchez-Madrid. 1995. Prevention of in vivo neutrophil-endothelial attachment through shedding of L-selectin by nonsteroidal antiinflammatory drugs. J. Clin. Invest. 95:1756-1765.

26. Robey, F.A., K. Ohura, S. Futaki, N. Fujii, H. Yajima, N.D. Goldman, K.D. Jones, and S. Wahl. 1987. Proteolysis of human C-reactive protein produces peptides with potent immunomodulatory activity. J. Biol. Chem. 262 7053-7057.

27. Shephard, E.G., R. Anderson, D. Rosen, and M. Fridkin. 1992. C-reactive protein (CRP) peptides inactivate enolase in human neutrophils leading to depletion of intracellular ATP and inhibition of superoxide generation. Immunology. 76:79-85.

28. Goetzl, E.J., and K.F. Austen. 1976. Structural determinants of the eosinophil chemotactic activity of the acidic tetrapeptides of eosinophil chemotactic factor of anaphylaxis. J. Exp. Med. 144:1424-1432.

29. Barna, B.P., D.A. Eppstein, M.J. Thomassen, J.J. Nestor, Jr., T. Ho, S.V. Medendorp, and S.D. Deodhar. 1993. Therapeutic effects of a synthetic peptide of C-reactive protein in pre-clinical tumor models. Cancer Immunol. Immunother. 36:171-176.

30. Barna, B.P., M.J. Thomassen, P. Zhou, J. Pettay, S. Singh-Burgess, and S.D. Deodhar. 1996. Activation of alveolar macrophage TNF and MCP-1 expression in vivo by a synthetic peptide of C-reactive protein. J. Leukocyte Biol. 59:397-402.

31. Berg, M., and S.P. James. 1990. Human neutrophils release the Leu- 8 lymph node homing receptor during cell activation. Blood. 76:2381-2388.

32. Miller, L.J., D.F. Bainton, N. Borregaard, and T.A. Springer. 1987. Stimulated mobilization of monocyte Mac-1 and p150,95 adhesion proteins from an intracellular vesicular compartment to the cell surface. J. Clin. Invest. 80:535-544.

33. Kahn, J., R.H. Igraham, F. Shirley, G.I. Migaki, and T.K. Kishimoto. 1994. Membrane-proximal cleavage of L-selectin: identification of the cleavage site and a 6-kD transmembrane peptide fragment of L-selectin. J. Cell Biol. 125: 461-470.

34. Tedder, T.F., D.A. Steeber, A. Chen, and P. Engel. 1995. The selectins: vascular adhesion molecules. FASEB (Fed. Am. Soc. Exp. Biol.) J. 9:866-873.

35. Palecanda, A., B. Walcheck, D.K. Bishop, and M.A. Jutila. 1992. Rapid activation-independent shedding of leukocyte L-selectin induced by cross-linking of the surface antigen. Eur. J. Immunol. 22:1279-1286.

36. Migaki, G.I., J. Kahn, and T.K. Kishimoto. 1995. Mutational analysis of the membrane-proximal cleavage site of L-selectin: relaxed sequence specificity surrounding the cleavage site. J. Exp. Med. 182:549-557.

37. Chen, A., P. Engel, and T.F. Tedder. 1995. Structural requirements regulate endoproteolytic release of the L-selectin (CD62L) adhesion receptor from the cell surface of leukocytes. J. Exp. Med. 182:519-530.

38. Du Clos, T.W. C. Mold, P.Y. Paterson, J. Alroy, and H. Gewurz. 1981. Localization of C-reactive protein in inflammatory lesions of experimental allergic encephalomyelitis. Clin. Exp. Immunol. 43:565-573.

39. Vigushin, D.M., M.B. Pepys, and P.N. Hawkins. 1993. Metabolic and scintigraphic studies of radioiodinated human C-reactive protein in health and disease. J. Clin. Invest. 91:1351-1357.

40. Shields, M.J. 1993. A hypothesis resolving the apparently disparate activities of native and altered forms of human C-reactive protein. Immunol. Res. $12: 37-47$ 